\title{
Analysis of Titania Nanosheet Adsorption Behavior Using a Quartz Crystal Microbalance Sensor
}

\author{
Yuichiro Tashiro, ${ }^{1}$ Satoshi Komasa ${ }^{(D)},{ }^{1}$ Akiko Miyake $\left(\mathbb{D},{ }^{2}\right.$ Hiroshi Nishizaki $\left(\mathbb{D},{ }^{1}\right.$ \\ and Joji Okazaki $\mathbb{D}^{1}$ \\ ${ }^{1}$ Department of Removable Prosthodontics and Occlusion, Osaka Dental University, 8-1 Kuzuhahanazono-cho, Hirakata-shi, \\ Osaka, Japan \\ ${ }^{2}$ Department of Oral Health Engineering, Faculty of Health Sciences, Osaka Dental University, 1-4-4 Makino-honmachi, \\ Hirakata-shi, Osaka, Japan
}

Correspondence should be addressed to Satoshi Komasa; komasa-s@cc.osaka-dent.ac.jp

Received 17 August 2017; Accepted 29 November 2017; Published 19 February 2018

Academic Editor: Marco Cannas

Copyright (c) 2018 Yuichiro Tashiro et al. This is an open access article distributed under the Creative Commons Attribution License, which permits unrestricted use, distribution, and reproduction in any medium, provided the original work is properly cited.

\begin{abstract}
We investigated the adsorption of albumin and fibronectin on a titania nanosheet- (TNS-) modified quartz crystal microbalance (QCM) sensor. A Ti QCM sensor was fabricated by reactive magnetron sputtering. A thin layer of Ti was deposited on the QCM sensor. This sensor was then alkali-modified by treatment with $\mathrm{NaOH}$ at room temperature to fabricate the titania nanosheets. Scanning probe microscopy, X-ray photoelectron spectroscopy, and scanning electron microscopy were performed to investigate the surface topology and chemical components of each sensor. The TNS had a titanium oxide film exhibiting a nodular structure and a thickness of $13 \mathrm{~nm}$ on the QCM sensor. Furthermore, QCM measurements showed significantly greater amounts of albumin and fibronectin adsorbed on the TNS than on titanium. The $\mathrm{NaOH}$ treatment of titanium modified the sensor surface and improved the adsorption behaviors of proteins related to the initial adhesion of bone marrow cells. Therefore, we concluded that TNS improves the initial adhesion between the implant materials and the surrounding tissues.
\end{abstract}

\section{Introduction}

Titanium is a biocompatible material that is commonly used in dentistry and orthopedic reconstruction. The surface features of implant materials have important functions in cell or extracellular matrix interrelationships and eventual osseointegration. Therefore, interrelationships between cells and microtopography have been intensively studied.

An important contemporary advance in dental implant research is the ability to modify implant surface materials at the nanoscale $[1,2]$. Materials with an expanded surface region and a better surface roughness may yield better mechanical interlocking between tissues and titanium [3]. However, more importantly, such nanoscale features are also believed to directly affect osteogenic cell behaviors around implant fixtures with nonconventional surfaces, creating a biomimetic relationship between alloplastic surfaces and host tissues by the replication of the natural cellular environment at the nanometer level $[1,2,4]$.
Low-dimensional $\mathrm{TiO}_{2}$ nanostructures have attracted recent attention because these materials can take the forms of nanotubes [5], nanofibers [6], and nanowires [7]. Compared with mass materials or nanoparticles, $\mathrm{TiO}_{2}$ nanotubes have high particular surface zones accessible for the adsorption of color sensitizers, and they provide channels to improve electron exchange, thus expanding the effectiveness of solar cells [5]. Titania nanosheets (TNSs) are similar to $\mathrm{TiO}_{2}$ nanotubes, created by titania deposition using the sputtering process [5].

In our previous study [8], we showed that TNSs created by compound processing enhance the osteogenic separation of rodent bone marrow (RBM) cells. The surface properties and structural characteristics of materials play an important role in protein and cell adsorption behaviors. The initial amount adsorbed and the conformation of proteins contained in the serum could alter the bioactivity of stem cells on TNSs. However, the bioactivities of TNS materials, including their roles in osteogenic differentiation and the 
biointegration of dental implants into the alveolar bone, have not been elucidated.

A quartz crystal microbalance (QCM) sensor is a profoundly delicate and handy device that is used to observe protein adsorption and cell behavior in situ. A QCM-based sensor comprises a quartz crystal and a detection material. A $27 \mathrm{MHz}$ QCM can provide highly sensitive measurements of mass in aqueous solutions; the resonance frequency decreases in relation to the mass of the protein bound on the QCM electrode surface. We previously fabricated several types of QCM sensors by coating the gold electrode of the quartz crystal with a thin film of a biomaterial [9]; this QCM sensor achieved an increase in sensitivity approximately 24 times that of a conventional $5 \mathrm{MHz}$ QCM. PMMA (poly (methyl methacrylate)), Au, and Ti have been used as QCM electrode surface materials to imitate denture materials and evaluate the adsorption behaviors of various bovine salivary proteins [10]. These previous findings support the potential utility of the QCM method for the evaluation of protein adsorption behaviors on implant surfaces.

In this study, we evaluated the effects of modified surfaces on the adsorption of albumin and fibronectin in RBM cells and simulated body fluid (SBF) in QCM analyses.

\section{Materials and Methods}

2.1. Sputtering Procedure. A thin layer of Ti was deposited on quartz discs (diameter: $8 \mathrm{~mm}$, area: $4.9 \mathrm{~mm}^{2}$ ) by reactive magnetron sputtering using a radio-frequency magnetron sputtering system (CFS-4ES-231; Shibaura Mechatronics Co., Ltd., Kanagawa, Japan). The QCM crystal was cleaned using piranha solution $\left(\mathrm{H}_{2} \mathrm{SO}_{4} / 30 \% \mathrm{H}_{2} \mathrm{O}_{2}(\mathrm{v} / \mathrm{v}): 7: 3\right)$. Before deposition was conducted, the quartz surfaces were ultrasonically cleaned in high-purity acetone (99.999\%). Pure Ti powder was used to prepare the target, which was formed by pressing the powder into a disc with a diameter of $75 \mathrm{~mm}$. The quartz substrates were positioned $85 \mathrm{~mm}$ above the target, and the magnetron sputtering chamber was evacuated to a pressure of $3 \times 10^{-3} \mathrm{~Pa}$. Argon was used as the working gas, and its pressure was kept constant at $6.7 \times 10^{-1} \mathrm{~Pa}$. All of the films were fabricated using a constant radio-frequency discharge power of $480 \mathrm{~W}$, and the Ti thin films were deposited at room temperature at a deposition rate of $20.0 \mathrm{~nm} / \mathrm{min}$, yielding a film thickness of approximately $240 \mathrm{~nm}$. The crystals were washed and cleaned with both sodium dodecyl sulfate and UVOzone Cleaner (PC450; Meiwafosis Co., Ltd., Osaka, Japan) prior to QCM measurements.

2.2. Sample Preparation. In the TNS group, Ti sensors were treated to produce TNS on their surfaces. An unprocessed QCM sensor was used as the Ti sensor. These sensors were immersed in $10 \mathrm{M} \mathrm{NaOH}(\mathrm{aq})$ and were then placed in an oil bath, which was kept at a temperature of $30^{\circ} \mathrm{C}$ for $24 \mathrm{~h}$. The solution in each flask was replaced and treated with distilled water $(200 \mathrm{~mL})$, and this procedure was repeated until the point that a conductivity of $5 \mu \mathrm{S} / \mathrm{cm}^{3}$ was reached. The specimens were then dried at room temperature.
2.3. Characterization of Materials. Scanning electron microscopy (S-4800; Shimadzu, Kyoto, Japan) and scanning probe microscopy (SPM-9600; Shimadzu) over a surface area of $2.0 \mu \mathrm{m} \times 2.0 \mu \mathrm{m}$ were conducted to observe the surface topology and roughness of the fabricated TNS and Ti sensors. The composition of the coating was analyzed by X-ray photoelectron spectroscopy (XPS; ESCA 5600, UlvacPhi Inc., Kanagawa, Japan) using surface etching with ionized argon. In addition, the surfaces of the fabricated $\mathrm{Ti}$ sensors were subjected to XPS analysis with an Al K $\alpha$ line $(15 \mathrm{kV}, 300 \mathrm{~W})$ as an X-ray source. During XPS, argon ion sputtering was applied to determine the thickness and structure of the surface layers.

2.4. Contact Angle Measurements. Contact angles were measured for the TNS and Ti sensors using a video contact angle measurement system (model VSA 2500 XE; AST Products Inc., Billerica, MA, USA). A small droplet of a deionized water solution with Hanks' Balanced Salt Solution and bovine serum albumin (BSA; approximately $3 \mathrm{mg}$ ) was placed on the TNS to measure the static contact angle. Estimation of the contact edge is a straightforward strategy for breaking down the vitality and hydrophilic nature of a surface.

2.5. Proteins. BSA (Wako Pure Chemical Industries Ltd., Osaka, Japan) was dissolved in phosphate-buffered saline (PBS; pH 7.4) at $200 \mu \mathrm{g} / \mathrm{mL}$. Human plasma fibronectin (HFN; Nacalai Tesque, Inc., Kyoto, Japan) was dissolved in PBS (pH 7.4) at $500 \mu \mathrm{g} / \mathrm{mL}$.

2.6. Cell Culture. Since most bone embed materials are embedded in adult bone that is in direct contact with bone marrow tissue, the effects and success of new embed materials can be investigated by examining bone marrow cell cultures from adult rats. RBM cells multiply and separate into a phenotype that expresses bone cell markers in vitro. RBM cells were extracted from the femurs of 7-week-old Sprague-Dawley rats. The rats were humanely sacrificed utilizing $4 \%$ isoflurane, and the bones were aseptically extracted from the hind limbs. The external soft tissues were discarded, and the extracted bone samples were immersed in $50 \mathrm{~mL}$ of Eagle's minimal essential medium (EMEM; Wako) supplemented with $20 \%$ fetal bovine serum (lot number 1,412,447; Invitrogen, Life Technologies Corp., Carlsbad, CA, USA) and penicillin $(850 \mathrm{U} / \mathrm{mL})$ for approximately $15 \mathrm{~min}$.

The proximal end of the femur and the distal end of the tibia were cut. An 18-gauge needle (TERMO, Japan) was introduced into the opening at the knee-joint end of each bone, and the marrow was washed out of the bone shaft by EMEM. The obtained marrow pellet was separated by trituration, and the cell suspensions obtained from all the bones were combined by centrifugation. RBM cells were cultured in $75 \mathrm{~cm}^{2}$ culture flasks (TD75; Falcon) in EMEM. At confluence, the cells were removed by trypsinization, washed twice in EMEM, resuspended in culture medium, 
and seeded on test and control titanium disks at a concentration of $4 \times 10^{4}$ cells $/ \mathrm{cm}^{2}$ in 24-well tissue culture plates. The cells were incubated for 3 days in a $\mathrm{CO}_{2}$ incubator at $37^{\circ} \mathrm{C}$. This investigation was conducted in accordance with the Guidelines for Animal Experimentation of Osaka Dental University (Approval no. 16-08001).

2.7. QCM Measurements. The amounts of proteins (BSA and HFN) and RBM cells were determined by QCM measurements (Affinix QN $\mu$; Initium Co., Ltd., Tokyo, Japan). Affinix QN $\mu$ had a $550 \mu \mathrm{L}$ cell outfitted with a $27 \mathrm{MHz}$ QCM plate at the base of the cell. The diameter of the quartz plate was $8 \mathrm{~mm}$, and the area of the gold-plated quartz was $4.9 \mathrm{~mm}^{2}$. The unit also included a mixing bar and a temperature controller. The adjustment in recurrence was checked utilizing a universal frequency counter connected to a microcomputer.

The Ti QCM sensors and TNS were immersed in $500 \mu \mathrm{L}$ of PBS (0.01 M PBS at pH 7.4). Changes in the QCM frequency were measured as a function of time; recording started immediately after the infusion of $5 \mu \mathrm{L}(20 \mu \mathrm{g} / \mathrm{mL})$ of BSA, HFN, and RBM cells. The solution was mixed to avoid any influence of protein dispersion on the measured results. Stirring did not influence the soundness of the frequency or the degree of frequency adjustment. The frequency change relied upon the adsorbed mass in accordance with the Sauerbrey equation:

$$
\Delta F=-\frac{2 F_{0}^{2} \Delta m}{A \sqrt{\rho_{q} \mu_{q}}}
$$

As per this condition, at $27 \mathrm{MHz}$, a frequency shift of $1 \mathrm{~Hz}$ relates to a mass difference in roughly $0.62 \mathrm{ng} \cdot \mathrm{cm}^{-2}$. In the Sauerbrey equation, $F_{0}$ is the fundamental frequency of the quartz crystal $\left(27 \times 10^{6} \mathrm{~Hz}\right), \Delta F$ is the measured frequency shift $(\mathrm{Hz}), \rho_{q}$ is the density of quartz $\left(2.65 \mathrm{~g} \cdot \mathrm{cm}^{-3}\right)$, $\Delta m$ is the mass change (g), $A$ is the electrode area $\left(0.049 \mathrm{~cm}^{2}\right)$, and $\mu_{q}$ is the shear modulus of quartz $\left(2.95 \times 1011 \mathrm{dyn} \cdot \mathrm{cm}^{-2}\right)$. QCM observation was performed at $25^{\circ} \mathrm{C}$, and the test was repeated four times. Results are depicted as mean \pm standard deviation.

2.8. XPS Analysis after Measuring the Adsorption of BSA and HFN Using Ti and TNS QCM Sensors. The biochemical constituents of the adsorbed protein films on the QCM sensors were investigated by XPS on an AXIS Ultra DLD spectrometer (Kratos Instruments, Manchester, UK) equipped with a monochromated $\mathrm{Al} \mathrm{K} \alpha \mathrm{X}$-ray source $(\mathrm{hv}=1486.6 \mathrm{eV})$ operated at $75 \mathrm{~W}$. XPS was utilized to investigate the proteinaceous carbon $(\mathrm{C} 1 \mathrm{~s})$ and nitrogen $(\mathrm{N} 1 \mathrm{~s})$ signals produced by the protein. Evaluation of the $\mathrm{C} 1 \mathrm{~s}$ and N1s signals emerging from the peptide bonds of the protein was conducted to determine the relative amount of protein adsorbed on various surfaces.

2.9. Preparation of $S B F$. Since $S B F$ is supersaturated with respect to apatite, improper planning can prompt the precipitation of apatite in the solution. Therefore, the solution should remain colorless and transparent, and there should not be any deposition on the inner surface of the container. If precipitation is observed, the preparation of SBF should be halted, and the procedure should be restarted at the step of washing the apparatus.

For preparation of $1 \mathrm{~L}$ of SBF, $700 \mathrm{~mL}$ of ion-exchanged and distilled water was added to a $1 \mathrm{~L}$ plastic beaker with a stir bar. The beaker was covered with plastic wrap, and the water was heated to $36.5 \pm 1.5^{\circ} \mathrm{C}$ under stirring. Reagents $1-8$ were then dissolved into the solution in order (given in Table 1) at $36.5 \pm 1.5^{\circ} \mathrm{C}$, and reagents 9 (Tris) and $10(\mathrm{HCl})$ were added after $\mathrm{pH}$ adjustment.

Note that during this procedure, instead of glass containers, plastic containers with smooth, unscratched surfaces were used because apatite nucleation can be induced on the surfaces of glass containers or the edges of scratches. Additionally, reagents were dissolved completely before addition of the next reagent. The volume of $1 \mathrm{M} \mathrm{HCl}$ was measured using a cylinder after the cylinder had been washed with $1 \mathrm{M} \mathrm{HCl}$. Finally, hygroscopic reagents, such as $\mathrm{KCl}, \mathrm{K}_{2} \mathrm{HPO}_{4} \cdot 3 \mathrm{H}_{2} \mathrm{O}, \mathrm{MgCl}_{2} \cdot 6 \mathrm{H}_{2} \mathrm{O}, \mathrm{CaCl}_{2}$, and $\mathrm{Na}_{2} \mathrm{SO}_{4}$, were measured as quickly as possible.

The temperature of the solution was set to $36.5 \pm 1.5^{\circ} \mathrm{C}$. If the amount of solution was less than $900 \mathrm{~mL}$, ion-exchanged and distilled water was added to increase the volume to $900 \mathrm{~mL}$. The $\mathrm{pH}$ of the solution was then determined. Before Tris was added to the solution and dissolved, the $\mathrm{pH}$ of the solution was $2.0 \pm 1.0$. The solution temperature was kept within the range of $35-38^{\circ} \mathrm{C}$ (optimal: $36.5 \pm 0.5^{\circ} \mathrm{C}$ ), and the added Tris was dissolved slowly, while changes in $\mathrm{pH}$ were noted. Tris was added until the $\mathrm{pH}$ reached approximately 7.45 .

\section{Results}

3.1. Scanning Electron Microscopy (SEM) and SPM Analysis. SEM images are shown in Figure 1. After modification in $\mathrm{NaOH}$ at $30^{\circ} \mathrm{C}$, the TNS sensor surfaces showed a nanoscale network structure. SPM was utilized to gauge the depth of the surface characteristics of the specimens, and the surface morphologies of the TNS and Ti sensors are shown in Figure 2. Many nanonodules were detected on the TNS surface; these formations had horizontal dimensions of approximately $300 \mathrm{~nm}$. The surface roughness $(\mathrm{Ra})$ values were 3.9 and $18.9 \mathrm{~nm}$ for the Ti and TNS sensors, respectively.

3.2. XPS Analysis. Figure 3 shows the results of wide-scan XPS surface chemical analyses of Ti and TNS QCM sensors. The presence of $\mathrm{Ti}, \mathrm{O}, \mathrm{C}$, and $\mathrm{N}$ was confirmed on the surfaces of $\mathrm{Ti}$ and TNS QCM sensors. In addition, the presence of $\mathrm{Na}$ was confirmed on the surface of the TNS QCM sensor. Moreover, the Ti and $\mathrm{O}$ concentrations of TNS QCM sensors were higher than those on the surface of TNS QCM sensors.

3.3. Surface Wettability. The contact angle for a water drop on the Ti sensor was $42.5^{\circ}$. However, the water drops spread very rapidly as they reached the test sensor, and the contact angle could not be determined. However, the behavior on 
TABLE 1: Order, amounts, weighing containers, purities, and formula weights of reagents for the preparation of $1 \mathrm{~L}$ of SBF.

\begin{tabular}{|c|c|c|c|c|c|}
\hline Order & Reagent & Amount & Container & Purity (\%) & Formula weight \\
\hline 1 & $\mathrm{NaCl}$ & $8.035 \mathrm{~g}$ & Weighing paper & 99.5 & 58.4430 \\
\hline 2 & $\mathrm{NaHCO}_{3}$ & $0.355 \mathrm{~g}$ & Weighing paper & 99.5 & 84.0068 \\
\hline 3 & $\mathrm{KCl}$ & $0.225 \mathrm{~g}$ & Weighing bottle & 99.5 & 74.5515 \\
\hline 4 & $\mathrm{~K}_{2} \mathrm{HPO}_{4} \cdot 3 \mathrm{H}_{2} \mathrm{O}$ & $0.231 \mathrm{~g}$ & Weighing bottle & 99.0 & 228.2220 \\
\hline 5 & $\mathrm{MgCl}_{2} \cdot 6 \mathrm{H}_{2} \mathrm{O}$ & $0.311 \mathrm{~g}$ & Weighing bottle & 98.0 & 203.3034 \\
\hline 6 & $1.0 \mathrm{M} \mathrm{HCl}$ & $39 \mathrm{~mL}$ & Graduated cylinder & - & - \\
\hline 7 & $\mathrm{CaCl}_{2}$ & $0.292 \mathrm{~g}$ & Weighing bottle & 95.0 & 110.9848 \\
\hline 8 & $\mathrm{Na}_{2} \mathrm{SO}_{4}$ & $0.072 \mathrm{~g}$ & Weighing bottle & 99.0 & 142.0428 \\
\hline 9 & Tris & $6.118 \mathrm{~g}$ & Weighing paper & 99.0 & 121.1356 \\
\hline 10 & $1.0 \mathrm{M} \mathrm{HCl}$ & $0-5 \mathrm{~mL}$ & Syringe & - & - \\
\hline
\end{tabular}

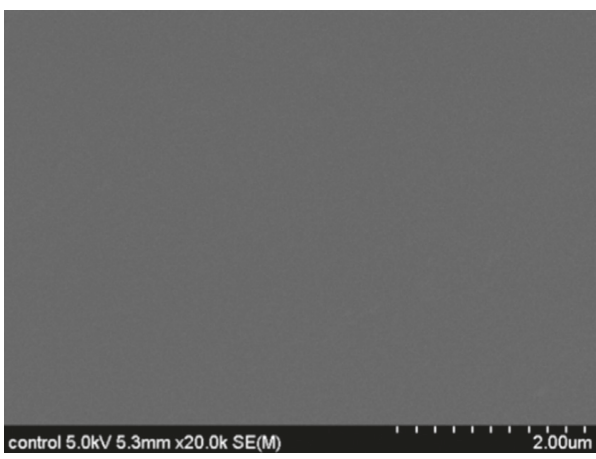

(a)

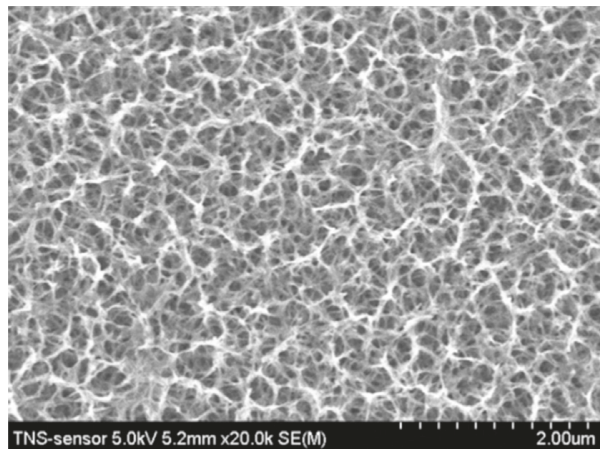

(b)

FIgURE 1: SEM images of (a) Ti and (b) TNS QCM sensors.

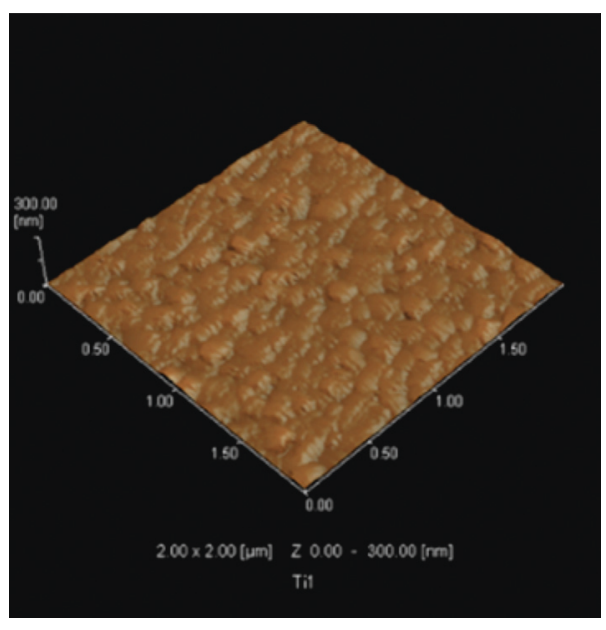

(a)

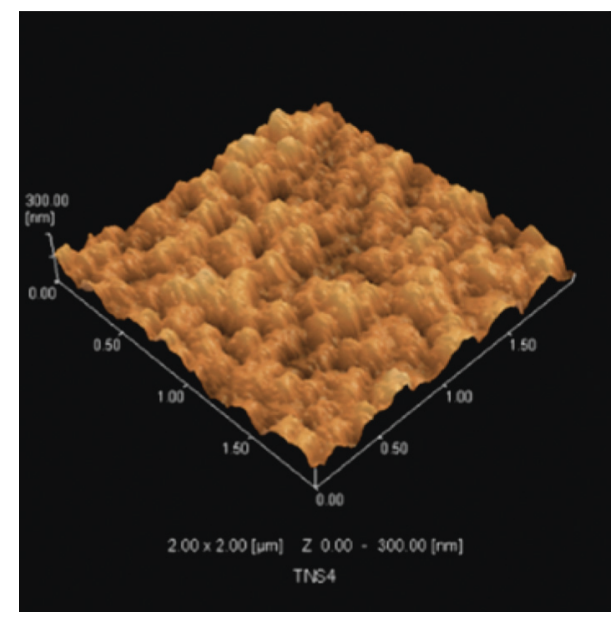

(b)

FIgURE 2: SPM images of (a) Ti and (b) TNS QCM sensors.

the TNS sensor indicated that the sensor was superhydrophilic (contact angle of less than $5^{\circ}$ ).

3.4. QCM Measurement of Proteins. Figure 4 shows the adsorption of albumin and fibronectin based on QCM measurements. An immediate decrease in frequency was observed after the injection of albumin and fibronectin. This decrease in frequency was identified with the adsorption of albumin and fibronectin. The adsorption of albumin and fibronectin on the TNS sensor produced a decrease in frequency that was greater than that measured for the $\mathrm{Ti}$ sensor. According to Sauerbrey's equation, at $27 \mathrm{MHz}$, a frequency decrease of $1 \mathrm{~Hz}$ compares to a mass difference of around $0.62 \mathrm{ng} / \mathrm{cm}^{2}$ [10]. After $30 \mathrm{~min}$, the amounts of albumin adsorbed on the TNS and Ti sensors were 187.8 and 


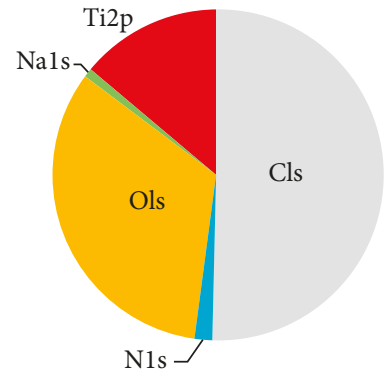

(a)

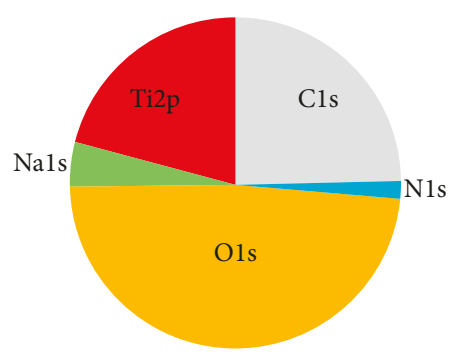

(b)

FIgURE 3: XPS analysis of (a) Ti and (b) TNS QCM sensors.

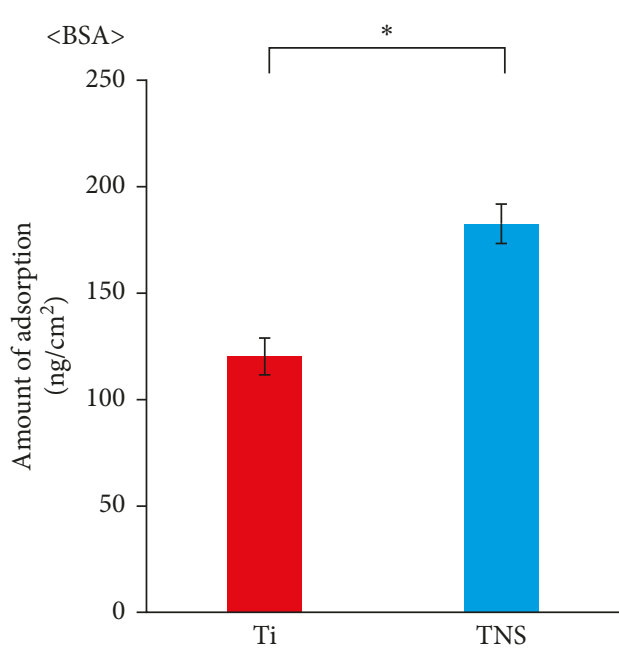

(a)

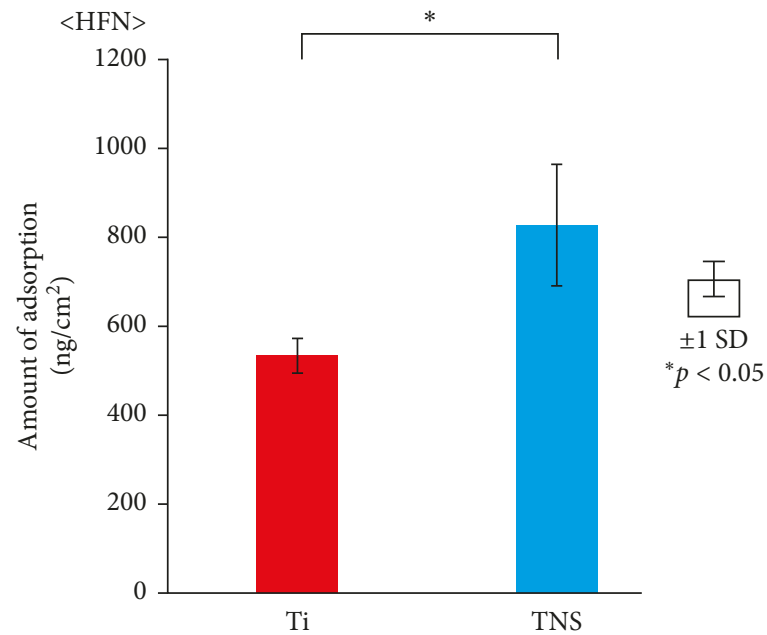

(b)

Figure 4: Adsorption of two proteins on Ti and TNS QCM sensors. (a) BSA. (b) HFN.

$117.5 \mathrm{ng} / \mathrm{cm}^{2}$, respectively, and the amounts of fibronectin adsorbed on the TNS and Ti sensors were 827.6 and $533.7 \mathrm{ng} / \mathrm{cm}^{2}$, respectively.

3.5. QCM Measurement of RBM Cells. Figure 5 shows the adsorption of rat bone marrow cells based on QCM measurements. An immediate decrease in frequency was observed after the injection of RBM cells. The adsorption of RBM cells on the TNS sensor produced a decrease in frequency that was greater than that measured for the Ti sensor. Using Sauerbrey's equation, after $30 \mathrm{~min}$, the amounts of albumin adsorbed on the TNS and Ti sensors were 1491.1 and $872.5 \mathrm{ng} / \mathrm{cm}^{2}$, respectively.

3.6. XPS Analysis after Adsorption of Proteins. The XPS spectra of the Ti and TNS QCM sensors after immersion in BSA are summarized in Figures 6 and 7, and those of the Ti and TNS QCM sensors after immersion in HFN are shown in Figures 8 and 9. For XPS analysis, the N1s and C1s spectra were measured. The coupling energies (BEs) of the $\mathrm{C} 1 \mathrm{~s}$ range for adsorbed BSA were $284.8 \mathrm{eV}$ (C-C/C-H), $286.4 \mathrm{eV}$ $(\mathrm{C}-\mathrm{O} / \mathrm{C}-\mathrm{N})$, and $288.2 \mathrm{eV}(\mathrm{O}=\mathrm{C}-\mathrm{O})$ for the Ti QCM sensors and $284.8 \mathrm{eV}(\mathrm{C}-\mathrm{C} / \mathrm{C}-\mathrm{H}), 286.4 \mathrm{eV}(\mathrm{C}-\mathrm{O} / \mathrm{C}-\mathrm{N})$, and $288.6 \mathrm{eV}$ $(\mathrm{O}=\mathrm{C}-\mathrm{O})$ for the TNS QCM sensors. There were N1s peaks

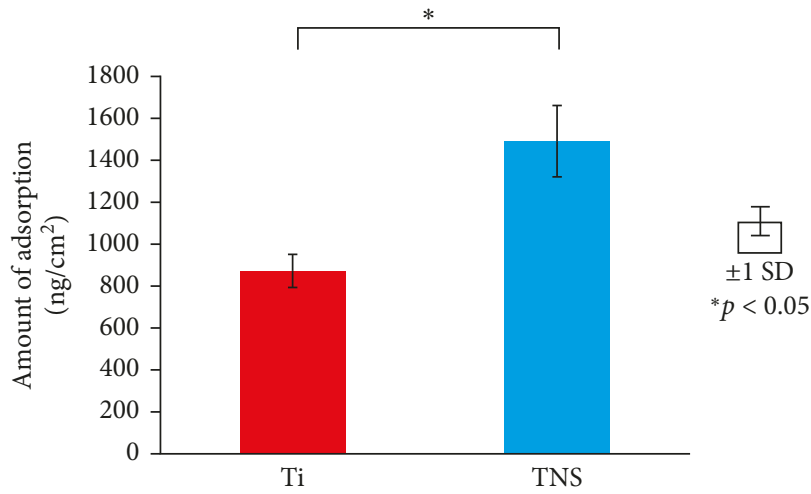

FIGURE 5: Adsorption of rat bone marrow cells on Ti and TNS QCM sensors.

for the Ti and TNS QCM sensors after the adsorption of BSA. The BEs of the $\mathrm{C} 1 \mathrm{~s}$ spectrum for adsorbed HFN were $284.8 \mathrm{eV}$ (C-C/C-H), $286.4 \mathrm{eV}(\mathrm{C}-\mathrm{O} / \mathrm{C}-\mathrm{N})$, and $288.0 \mathrm{eV}$ $(\mathrm{O}=\mathrm{C}-\mathrm{O})$ in the $\mathrm{Ti} \mathrm{QCM}$ sensors and $284.7 \mathrm{eV}(\mathrm{C}-\mathrm{C} / \mathrm{C}-\mathrm{H})$, $286.4 \mathrm{eV}(\mathrm{C}-\mathrm{O} / \mathrm{C}-\mathrm{N})$, and $288.0 \mathrm{eV}(\mathrm{O}=\mathrm{C}-\mathrm{O})$ for the TNS QCM sensors. After adsorption of the HFN, there were also N1s center-level spectra for the Ti and TNS QCM sensors. 


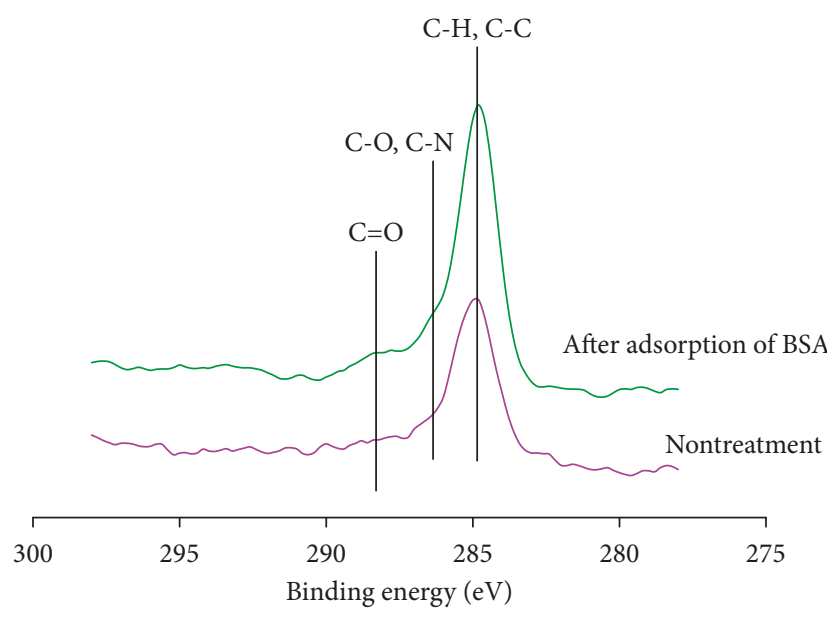

(a)

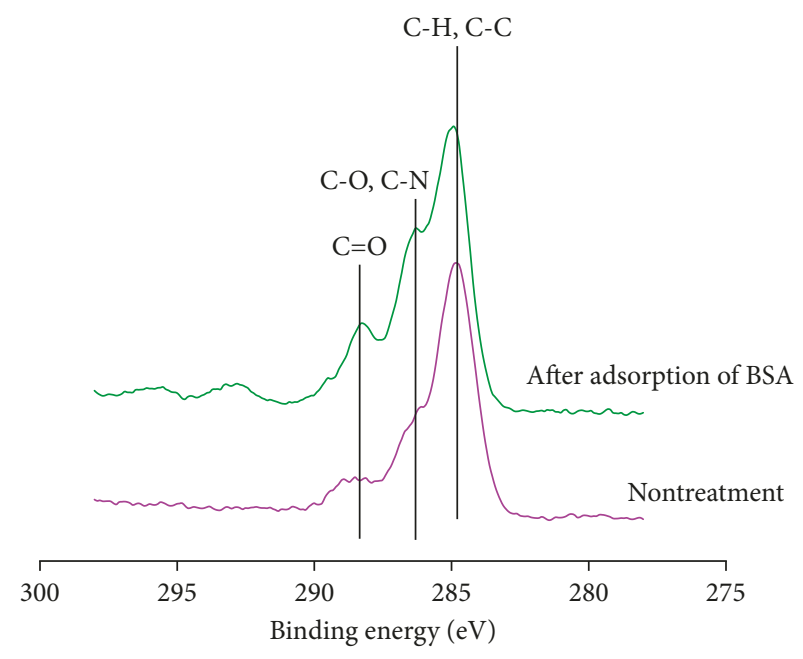

(b)

Figure 6: C1s XPS spectra of (a) Ti and (b) TNS QCM sensors after immersion in BSA.

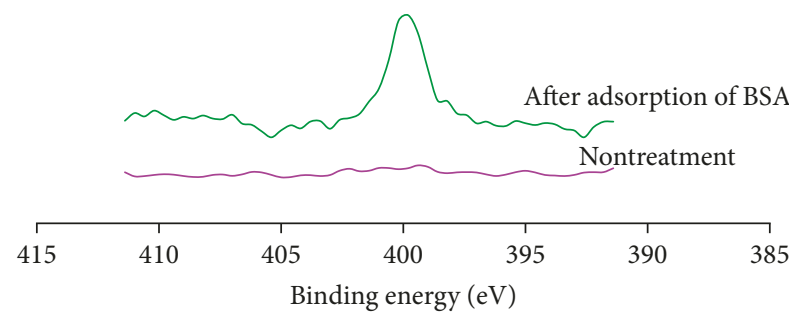

(a)

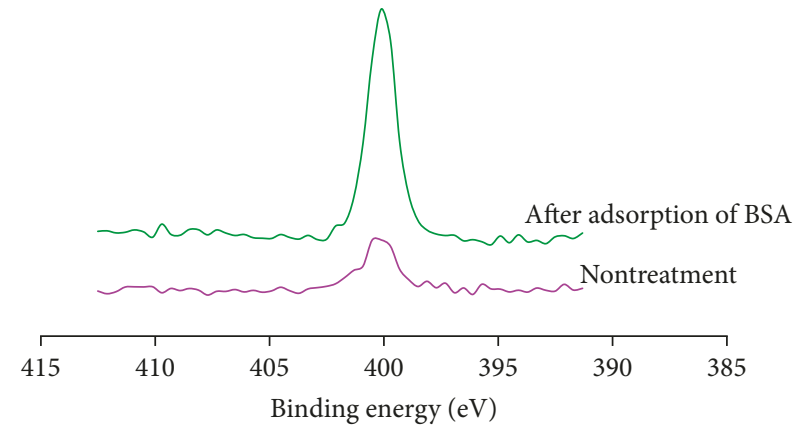

(b)

FIgURE 7: N1s XPS spectra of (a) Ti and (b) TNS QCM sensors after immersion in BSA.

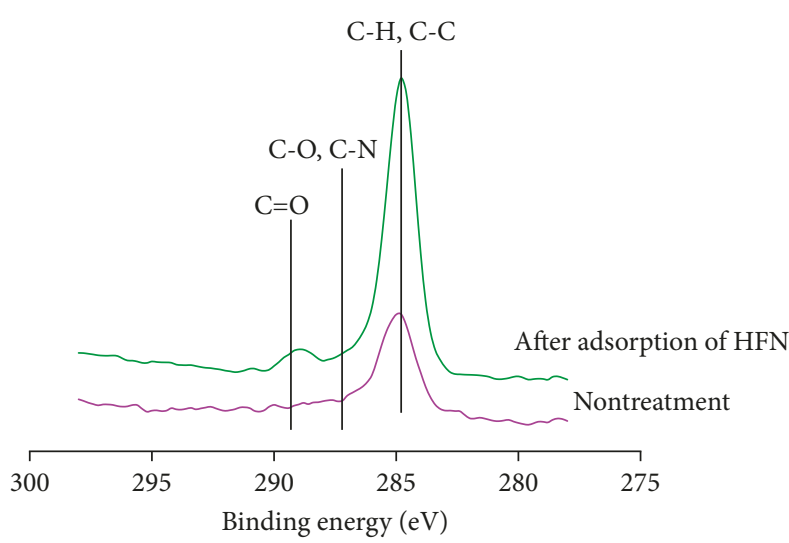

(a)

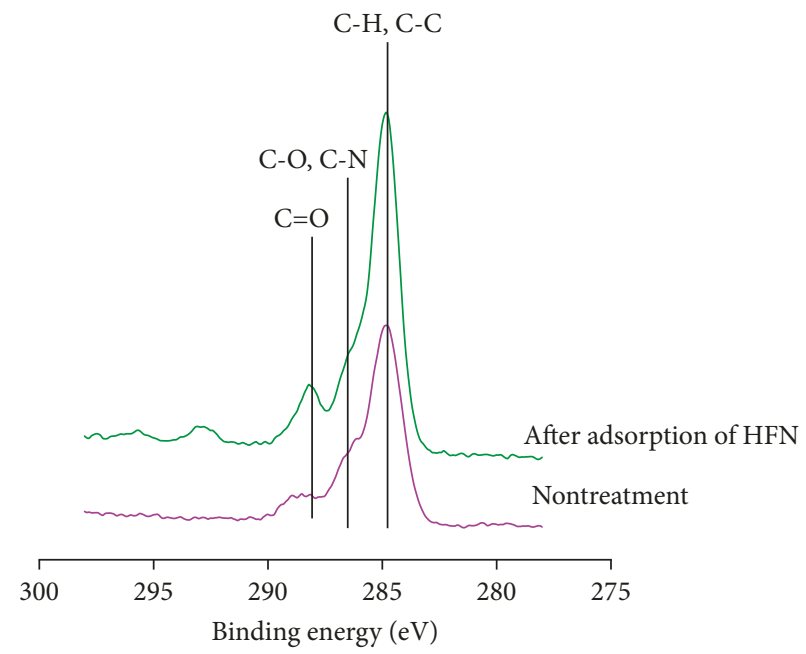

(b)

FIGURE 8: C1s XPS spectra of (a) Ti and (b) TNS QCM sensors after immersion in HFN.

3.7. Characterization after Immersion in SBF. Figure 10 shows the adsorption of apatite after exposure to the SBF solution based on QCM measurements. A quick frequency reduction was seen after the infusion of SBF. The adsorption of SBF on the TNS sensor produced a decrease in the frequency that was greater than that measured for the Ti sensor. 


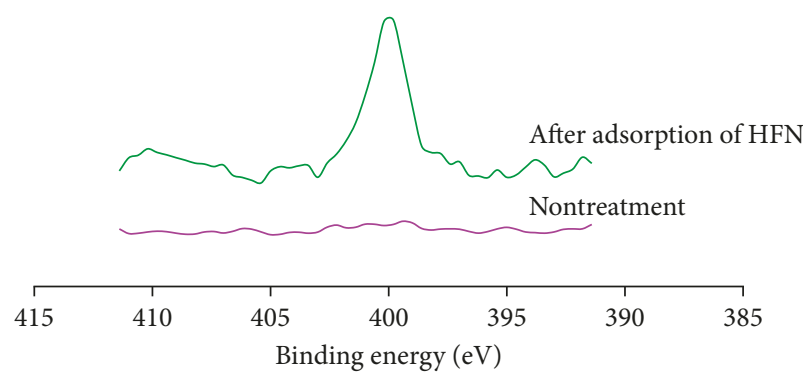

(a)

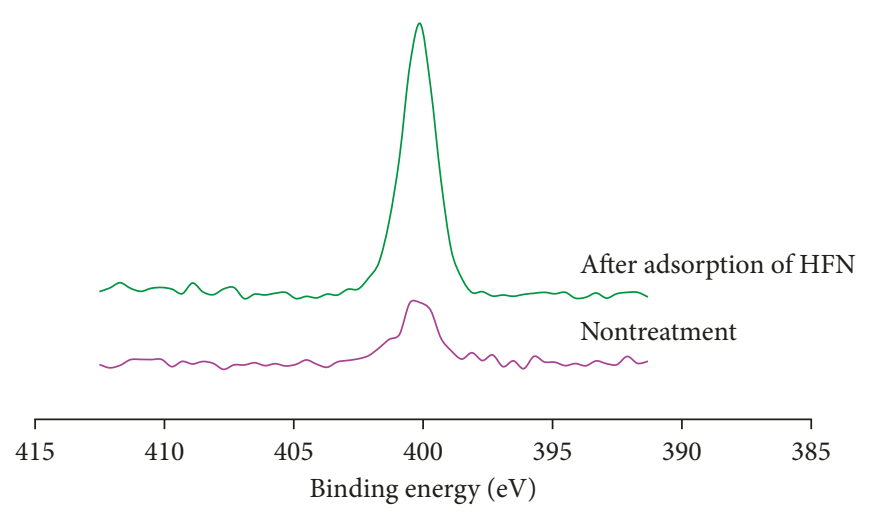

(b)

Figure 9: N1s XPS spectra of (a) Ti and (b) TNS QCM sensors after immersion in HFN.

Figure 11 shows the surface morphology of the Ti and TNS QCM sensors after immersion in SBF for $24 \mathrm{~h}$. After immersion, a recently framed layer was seen on the Ti and TNS surfaces. The surface was covered by single and grouped ball-like particles with a size of around $1.5 \mu \mathrm{m}$. The number of particles on the surface of the TNS QCM sensor was clearly greater than that on the surface of the Ti QCM sensor.

\section{Discussion}

In this study, $\mathrm{Ti}$ sensors were realized by depositing a thin $\mathrm{Ti}$ film on a QCM electrode using a reactive DC magnetron sputtering technique; this sensor was further alkali modified using $\mathrm{NaOH}$ treatment to fabricate the TNS. SPM and XPS analyses were carried out to characterize the nanostructure of the TNSs. We evaluated the quality of the TNSs and the potential application of the high-frequency TNS sensors by investigating the in situ binding behaviors for TNS sensors, two proteins, RBM cells, and SBF to determine the effects of these parameters on biological reactions in solution.

Several studies have demonstrated that implant surfaces affect nanoscale topography and thereby alter cell behaviors or change the nanofeatures of structures to improve the osseointegration process $[4,11,12]$. The embed surface can be adjusted by various approaches to add nanoscale features to the surfaces in specific combinations. The most wellknown techniques are chemical processes, such as alkaline hydrothermal $[13,14]$ or acid $[15,16]$ oxidation, on titanium surfaces to produce diverse nanoscale topographies. Kasuga et al. [5] demonstrated that $\mathrm{TiO}_{2}$ nanotubes with a diameter of about $8 \mathrm{~nm}$ and a length of about $100 \mathrm{~nm}$ could be formed by Ti treatment with a $10 \mathrm{M} \mathrm{NaOH}$ aqueous solution for $20 \mathrm{~h}$ at $110^{\circ} \mathrm{C}$, without the need for templates or replication. Essential factors in regulating cell reactions at the implanttissue interface can dramatically affect tissue coordination [17]. In a recent work, we demonstrated that $\mathrm{TiO}_{2}$ nanotubes and TNSs could be formed on titanium metal surfaces by treatment with a $10 \mathrm{M} \mathrm{NaOH}$ aqueous solution at $30^{\circ} \mathrm{C}$, and we used this method to prepare TNS-modified disks. Komasa et al. [8] suggested that TNSs on titanium surfaces can be applied to control the osteogenic differentiation of bone marrow cells and enhance mineralization. Our results

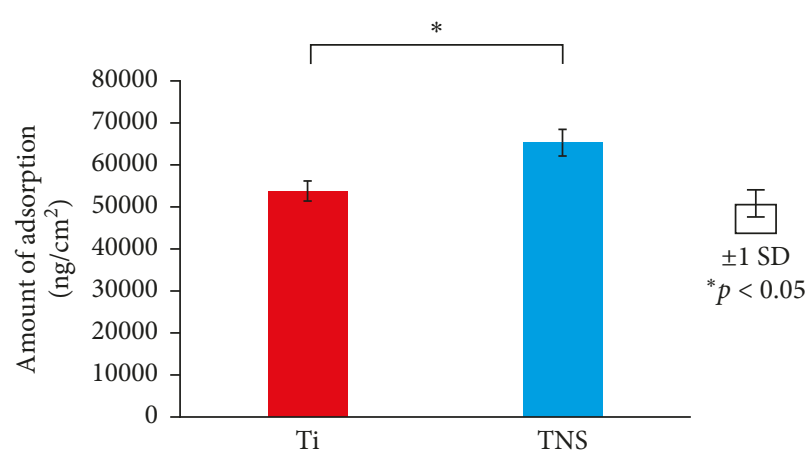

Figure 10: Adsorption of apatite on Ti and TNS QCM sensors.

demonstrated that TNS-modified titanium disks were more hydrophilic and showed uniquely enhanced wettability in comparison with unmodified disks. Further studies of the surface roughness and topography of modified titanium alloy surfaces are needed to assess their wettability. $\mathrm{Ra}$ is a commonly used height parameter to describe implant surface roughness; Ra of the TNS-modified titanium surface was $19 \mathrm{~nm}$, which was greater than that of the untreated titanium surface. The contact angles of the alkali-treated titanium disks gradually decreased in comparison with those of the control group, indicating that the wettability of the surface of the test group was reduced by $\mathrm{NaOH}$ treatment. In previous studies, a surface roughness of between 13 and $16 \mathrm{~nm}$ was found to be optimal for RBM cell culture $[18,19]$. The nanonetwork structure framed on the titanium disks here was like the hierarchical structure outlined by Zhao et al. [12]. In their work, hierarchical nanotextured titanium surface topographies with TNS structures that mirrored the hierarchical structures of bone tissues were created by etching followed by anodization. Natural tissues are hierarchical structures of nanoscale building blocks organized in a structured way. Hierarchical structures composed of nanocomponents may give a more reasonable surface topography for bone marrow cell functions than simpler structures because they can better copy the structures of natural tissues. Our research revealed that $\mathrm{NaOH}$ treatment prompts the development of a Ti-O-Na titanate layer on the titanium surface. Thus, we expect that $\mathrm{NaOH}$ treatment 


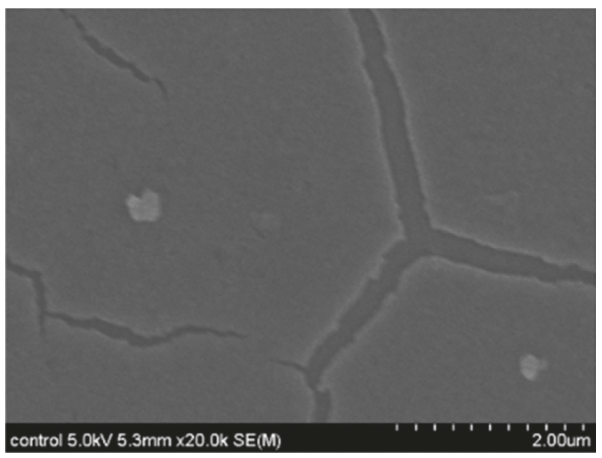

(a)

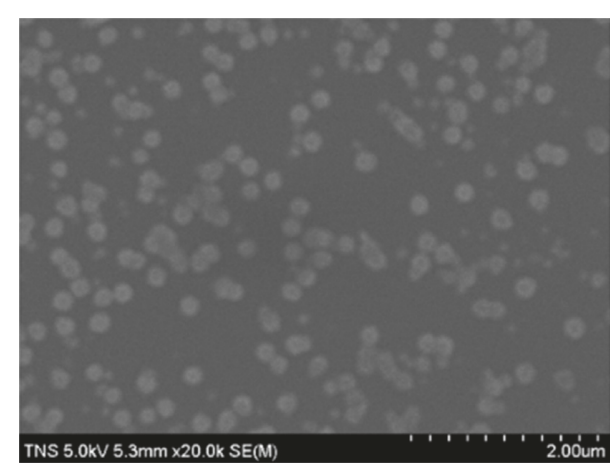

(b)

FIgURE 11: SEM images of exposure to SBF solution on (a) Ti and (b) TNS QCM sensors.

results in the formation of a thick oxide film on the $\mathrm{TiO}_{2}$ layer on the titanium surface. The deconvolution procedure suggested that this may have been due to surface contamination resulting from the binding of $\mathrm{O}$ to $\mathrm{C}[20]$.

Before argon ion etching was performed, the XPS depth profiles perpendicular to the surface of the sample showed a carbon contamination overlayer on the surface. This carbon contaminant was removed after the initial etching cycles. The oxygen and $\mathrm{Ti}$ concentrations gradually decreased and increased, respectively, as the number of etching cycles increased. Kim et al. [21] demonstrated that $\mathrm{NaOH}$ and heat treatment resulted in the covering of the $\mathrm{Ti}$ substrate with a titanium oxide layer with a thickness of approximately $1000 \mathrm{~nm}$; AES depth profiles of the Ti oxide layer indicated the presence of an amorphous sodium titanate hydrogel layer. Kasuga et al. [5] likewise showed that $\mathrm{NaOH}$ treatment prompted the formation of a Ti-O-Na titanate layer on the Ti surface. At a greater depth of approximately $250 \mathrm{~nm}$, the oxygen concentrations remained almost constant at 5 atom\%. In addition, the remaining oxygen content was approximately 5 atom\% inside the titanium film, which was attributed to the presence of residual oxygen in the chamber after preparation of the Ti sample.

All embed surfaces are promptly covered with a layer of protein from the in vitro culture medium or in vivo biological fluids, and this interface regulates the course of cell reactions and behaviors [22]. To elucidate the connection between the Ti implant surface properties, opsonization, and phagocytosis under in vivo conditions, phagocytic experiments were previously conducted using a cell culture medium supplemented with serum albumin and human opsonizing serum factors [23]. Fibronectin plays a crucial role in the progressive differentiation of osteoblasts [24]. Additionally, fibronectin has RGD sequences and is a large extracellular matrix dimer glycoprotein [25] with a molecular weight of approximately $440 \mathrm{kDa}$ [26]. Albumin is the most abundant plasma protein; it suppresses the adsorption of other proteins that may empower aggravation and bacterial colonization [27]. The molecular weight of BSA is approximately $6-7 \mathrm{kDa}$ [28]. In this study, the amount of fibronectin adsorbed was greater than the amount of albumin adsorbed, suggesting that adsorption quantity was related to the molecular weight of the injection solutions.
After adsorption of BSA and BSF, N1s core-level spectra were obtained for both QCM sensors. Endo [29] detected C, $\mathrm{O}$, and $\mathrm{N}$ obtained from the organic material or metal oxide on the titanium surface by XPS investigation. In the present study, based on XPS, the C1s and N1s peaks derived from BSA and BSF were detected on both QCM sensor surfaces tested. Evaluation of the N1s peak emerging from the peptide bonds of the implant-bone bonding protein may be a successful measure of the relative amount of protein adsorbed onto implant surfaces on the TNS QCM sensor.

Our results are the first comparison of RBM cell proliferation on TNS-modified titanium surfaces and unprocessed controls. Surfaces with nanostructures have higher surface areas than those of surfaces without such features $[11,30]$. This expanded surface territory permits increased adhesion of cells, such as osteoblasts and fibroblasts. Thus, the altered surface energies of materials with nanostructures may promote tissue growth via increased adsorption of select proteins compared with materials with microscale features [31]. The adsorption of select proteins can in this manner guide the adhesion of cells on the implant material surface, among other capabilities. Various investigations have exhibited improved cell adhesion and multiplication on nanostructured surfaces, with various potential tissue applications, including applications in the bladder, bone, vasculature, and nervous system [32-34]. A prior study suggested that TNSs on titanium surfaces facilitate the regulation of osteoblastic differentiation of bone marrow cells and enhance mineralization. The current study showed that the TNSs formed nanonodules with a diameter of about $19 \mathrm{~nm}$ on the titanium surfaces, and these structures promoted the adhesion and/or multiplication of cells. The network structure of TNSs on titanium alloy facilitated rapid cell adhesion, spreading, and multiplication due to the mechanics of the TNS structure and chemical nature of the Ti-O-Na layer.

To enhance bone-titanium bonding, Kokubo et al. recently demonstrated that a blend of alkalis resulted in the formation of bone-like apatite on the surface of titanium in SBF with an ion concentration almost equivalent to that of human blood [35]. Apatite development on the material surface is accepted to be essential for bioactivity, that is, direct bone bonding. In our study, there was an apatite layer 
on the TNS QCM sensor after $24 \mathrm{~h}$. Thus, the increased adhesion of RBM cells and SBF on the TNS QCM sensor suggested that TNS induced bone differentiation.

In the TNS sensor, the concentration of Ti exceeded that of oxygen at a depth of approximately $170 \mathrm{~nm}$. Subsequently, the $\mathrm{NaOH}$ treatment was thought to produce a thick oxide film. Nonetheless, the chemical structure of the treated surfaces did not vary fundamentally; Ti oxides (mostly $\mathrm{TiO}_{2}$ ) formed at the surface. Albumin and fibronectin were readily adsorbed, to a greater extent on the TNS sensor than on the reference Ti sensor. The TNS surface seemed to adsorb more protein for a given geometric surface area than the reference $\mathrm{Ti}$ sensor; this may have been a result of its rough morphology, as evidenced by the SEM and SPM results. Several studies $[36,37]$ have shown that nanostructured topographies can act as good mimics of natural extracellular matrixes. Advancement of the surface topography could be indirect; the adsorption of proteins or ions may function as an extension between the nanosurface structure and cells [38]. Webster et al. [39] observed increases in the adsorption of vitronectin on nanostructured surfaces (compared with conventional surfaces), which resulted in preferable adhesion of osteoblasts. In addition, here, the protein adsorption rate on the TNSs was correlated with the contact angle, suggesting that the hydrophilicity of titanium greatly affected its protein adsorption ability. The contact angle of the TNS and Ti sensors fluctuated in the hydrophilic range; the hydrophilicity of the surfaces expanded after treatment, corresponding to the formation of the TNSs. Thus, the growth of the titanium oxide layer increased the surface energy, resulting in a more hydrophilic surface [40].

\section{Conclusions}

In conclusion, TNS structures were obtained on a titanium surface via treatment with a $\mathrm{NaOH}$ aqueous solution at room temperature. Nanoscale network structures and a large number of nanoscale nodules were observed by SEM and SPM. In addition, the chemical composition of the TNS structures was estimated by XPS. The results confirmed the presence of a combined titanium and oxide titanate layer, which induced the adsorption of albumin and fibronectin. In the fields of tissue engineering and biomaterials, nanostructuring technologies are expected to yield novel, biologically optimized surfaces.

\section{Conflicts of Interest}

The authors declare that they have no conflicts of interest regarding the publication of this article.

\section{Authors' Contributions}

Satoshi Komasa conceived and designed the experiments; Yuichiro Tashiro performed the experiments; Yuichiro Tashiro, Satoshi Komasa, and Akiko Miyake analyzed the data; Hiroshi Nishizaki and Joji Okazaki contributed reagents, materials, and analysis tools; Yuichiro Tashiro and Satoshi Komasa wrote the paper.

\section{Acknowledgments}

The authors wish to express their thanks to Tohru Sekino from Osaka University for setting up the nanosheets and for his supportive recommendations. The authors are also grateful to the members of the Department of Removable Prosthodontics and Occlusion and the Department of Oral Health Engineering for their advice and assistance. The authors also thank Toshio Tamaki and Hirokazu Hojyo. This work was supported by grants from the Japan Society for the Promotion of Science (16K20524).

\section{References}

[1] M. Annunziata, A. Oliva, A. Buosciolo, M. Giordano, A. Guida, and L. Guida, "Bone marrow mesenchymal stem cell response to nano-structured oxidized and turned titanium surfaces," Clinical Oral Implants Research, vol. 23, no. 6, pp. 733-740, 2012.

[2] G. Mendonca, D. Mendonca, F. J. L. Aragao, and L. F. Cooper, "Advancing dental implant surface technology-From micronto nanotopography," Biomaterials, vol. 29 , no. 28 , pp. $3822-$ 3835, 2008.

[3] L. Meirelles, F. Currie, M. Jacobsson, T. Albrektsson, and A. Wennerberg, "The effect of chemical and nanotopographical modifications on the early stages of osseointegration," International Journal of Oral and Maxillofacial Implants, vol. 23, no. 4, p. 641, 2008.

[4] K. Kubo, N. Tsukimura, F. Iwasa et al., "Cellular behavior on $\mathrm{TiO}_{2}$ nanonodular structures in a micro-to-nanoscale hierarchy model," Biomaterials, vol. 30, no. 29, pp. 5319-5329, 2009.

[5] T. Kasuga, M. Hiramatsu, A. Hoson, T. Sekino, and K. Niihara, "Titania nanotubes prepared by chemical processing," Advanced Materials, vol. 11, no. 15, pp. 1307-1311, 1999.

[6] X. Gao, H. Zhu, G. Pan et al., "Preparation and electrochemical characterization of anatase nanorods for lithiuminserting electrode material," Journal of Physical Chemistry B, vol. 108, no. 9, pp. 2868-2872, 2004.

[7] A. R. Armstrong, G. Armstrong, J. Canales, and P. G. Bruce, “ $\mathrm{TiO}_{2}$ nanowires," Angewandte Chemie International, vol. 43, no. 17, pp. 2286-2288, 2004.

[8] S. Komasa, Y. Taguchi, H. Nishida, M. Tanaka, and T. Kawazoe, "Bioactivity of nanostructure on titanium surface modified by chemical processing at room temperature," Journal of Prosthodontic Research, vol. 56, no. 3, pp. 170-177, 2012.

[9] Y. Hashimoto, S. Minoura, A. Nishiura et al., "Development of titanium quartz crystal microbalance sensor by magnetron sputtering," Journal of Oral Tissue Engineering, vol. 8, pp. 52-59, 2010.

[10] A. Miyake, S. Komasa, Y. Hashimoto, Y. Komasa, and J. Okazaki, "Adsorption of saliva related protein on denture materials: an X-ray photoelectron spectroscopy and quartz crystal microbalance study," Advances in Materials Science and Engineering, vol. 2016, Article ID 5478326, 9 pages, 2016.

[11] G. Mendonca, D. B. Mendonca, F. J. Aragao, and L. F. Cooper, "The combination of micron and nanotopography by $\mathrm{H}(2) \mathrm{SO}(4) / \mathrm{H}(2) \mathrm{O}(2)$ treatment and its effects on osteoblast-specific gene expression of hMSCs," Journal of Biomedical Materials Research A, vol. 94, no. 1, pp. 169-179, 2010.

[12] L. Zhao, S. Mei, P. K. Chu, Y. Zhang, and Z. Wu, "The influence of hierarchical hybrid micro/nano-textured titanium surface with titania nanotubes on osteoblast functions," Biomaterials, vol. 31, no. 19, pp. 5072-5082, 2010. 
[13] W. Zhang, Z. Li, Y. Liu et al., "Biofunctionalization of a titanium surface with a nano-sawtooth structure regulates the behavior of rat bone marrow mesenchymal stem cells," International Journal of Nanomedicine, vol. 7, pp. 4459-4472, 2012.

[14] W. Dong, T. Zhang, J. Epstein et al., "Multifunctional nanowire bioscaffolds on titanium," Chemistry of Materials, vol. 19, no. 18, pp. 4454-4459, 2007.

[15] S. Bauer, J. Park, K. von der Mark, and P. Schmuki, "Improved attachment of mesenchymal stem cells on super-hydrophobic $\mathrm{TiO}_{2}$ nanotubes," Acta Biomaterials, vol. 4, no. 5, pp. 1576$1582,2008$.

[16] E. Hosono, H. Matsuda, I. Honma, M. Ichihara, and H. Zhou, "Synthesis of a perpendicular $\mathrm{TiO}_{2}$ nanosheet film with the superhydrophilic property without UV irradiation," Langmuir, vol. 23, no. 14, pp. 7447-7450, 2007.

[17] T. Albrektsson, P. I. Brånemark, H. A. Hansson, and J. Lindström, "Osseointegrated titanium implants: requirements for ensuring a long-lasting, direct bone-to-implant anchorage in man," Acta Orthopaedica, vol. 52, no. 2, pp. 155-170, 1981.

[18] H. Xing, S. Komasa, Y. Taguchi, T. Sekino, and J. Okazaki, "Osteogenic activity of titanium surfaces with nanonetwork structures," International Journal of Nanomedicine, vol. 9, p. 1741, 2014.

[19] T. Fujino, Y. Taguchi, S. Komasa, T. Sekino, and M. Tanaka, "Cell differentiation on nanoscale features of a titanium surface: effects of deposition time in $\mathrm{NaOH}$ solution," Journal of Hard Tissue Biology, vol. 23, no. 1, pp. 63-70, 2014.

[20] M. Pisarek, A. Roguska, M. Andrzejczuk et al., "Effect of twostep functionalization of Ti by chemical processes on protein adsorption," Applied Surface Science, vol. 257, no. 19, pp. 8196-8204, 2011.

[21] H. M. Kim, F. Miyaji, T. Kokubo, S. Nishiguchi, and T. Nakamura, "Graded surface structure of bioactive titanium prepared by chemical treatment," Journal of Biomedical Materials Research, vol. 45, pp. 100-107, 1999.

[22] M. Roser, D. Fischer, and T. Kissel, "Surface-modified biodegradable albumin nano-and microspheres. II: effect of surface charges on in vitro phagocytosis and biodistribution in rats," European Journal of Pharmaceutics and Biopharmaceutics, vol. 46, no. 3, pp. 255-263, 1998.

[23] P. Roach, D. Farrar, and C. C. Perry, "Interpretation of protein adsorption: surface-induced conformational changes," Journal of the American Chemical Society, vol. 127, no. 22, pp. 8168-8173, 2005.

[24] A. M. Moursi, C. H. Damsky, J. Lull et al., "Fibronectin regulates calvarial osteoblast differentiation," Journal of Cell Science, vol. 109, pp. 1369-1380, 1996.

[25] J. P. Quigley, L. I. Gold, R. Schwimmer, and L. M. Sullivan, "Limited cleavage of cellular fibronectin by plasminogen activator purified from transformed cells," Proceedings of the National Academy of Sciences U. S. A., vol. 84, no. 9, pp. 2776-2780, 1987.

[26] D. Khang, S. Y. Kim, P. Liu-Snyder, G. T. R. Palmore, S. M. Durbin, and T. J. Webster, "Enhanced fibronectin adsorption on carbon nanotube/poly (carbonate) urethane: independent role of surface nano-roughness and associated surface energy," Biomaterials, vol. 28, no. 32, pp. 4756-4768, 2007.

[27] C. McFarland, C. De Filippis, M. Jenkins et al., "Albuminbinding surfaces: in vitro activity," Journal of Biomaterials Science Polymer Edition, vol. 9, no. 11, pp. 1227-1239, 1998.

[28] A. Amaral, N. Alvarado, I. Marigomez, R. Cunha, K. Hylland, and M. Soto, "Autometallography and metallothionein immunohistochemistry in hepatocytes of turbot (Scophthalmus maximus L.) after exposure to cadmium and depuration treatment," Biomarkers, vol. 7, no. 6, pp. 491-500, 2002.

[29] K. Endo, Y. Araki, H. Ohno, and K. Matsuda, "ESCA analysis of tarnish films on dental alloys removed from the oral cavities (Part 1) Ag-In alloys," Journal of Dental Materials, vol. 7, pp. 184-191, 1988.

[30] K. Anselme, "Osteoblast adhesion on biomaterials," Biomaterials, vol. 21, no. 7, pp. 667-681, 2000.

[31] G. Balasundaram and T. J. Webster, "An overview of nanopolymers for orthopedic applications," Macromolecular Bioscience, vol. 7, no. 5, pp. 635-642, 2007.

[32] R. L. Price, K. Ellison, K. M. Haberstroh, and T. J. Webster, "Nanometer surface roughness increases select osteoblast adhesion on carbon nanofiber compacts," Journal of Biomedical Materials Research Part A, vol. 70, no. 1, pp. 129-138, 2004.

[33] R. Langer and D. A. Tirrell, "Designing materials for biology and medicine," Nature, vol. 428, no. 6982, pp. 487-492, 2004.

[34] L. Zhang and T. J. Webster, "Nanotechnology and nanomaterials: promises for improved tissue regeneration," Nano Today, vol. 4, no. 1, pp. 66-80, 2009.

[35] T. Kokubo, F. Miyaji, H. M. Kim, and T. Nakamura, "Spontaneous apatite formation on chemically surface treated Ti," Journal of the American Ceramic Society, vol. 79, no. 4, pp. 1127-1129, 1996.

[36] K. Woo, G. Wei, and P. Ma, "Enhancement of fibronectin-and vitronectin-adsorption to polymer/hydroxyapatite scaffolds suppresses the apoptosis of osteoblasts," Journal of Bone Mineral Research, vol. 17, p. 49, 2002.

[37] K. Woo, R. Zhang, H. Deng, and P. Ma, "Protein-mediated osteoblast survival and migration on biodegradable polymer/hydroxyapatite composite scaffolds," in Proceedings of Transactions of the 28th Annual Meeting of the Society for Biomaterials, Tampa, FL, USA, April 2002.

[38] V. Bucci-Sabattini, C. Cassinelli, P. G Coelho, A. Minnici, A. Trani, and D. M. D. Ehrenfest, "Effect of titanium implant surface nanoroughness and calcium phosphate low impregnation on bone cell activity in vitro," Oral Surgery, Oral Medicine, Oral Pathology, Oral Radiology, Endodontology, vol. 109, no. 2, pp. 217-224, 2010.

[39] T. J. Webster, C. Ergun, R. H. Doremus, R. W Siegel, and R. Bizios, "Specific proteins mediate enhanced osteoblast adhesion on nanophase ceramics," Journal of Biomedical Materials Research, vol. 51, no. 3, pp. 475-483, 2000.

[40] Y. Shibata, D. Suzuki, S. Omori et al., "The characteristics of in vitro biological activity of titanium surfaces anodically oxidized in chloride solutions," Biomaterials, vol. 31, no. 33, pp. 8546-8555, 2010. 


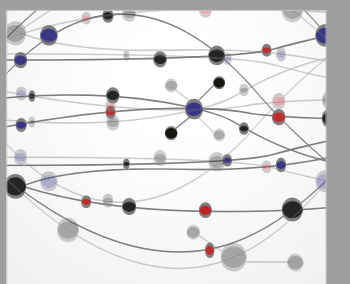

The Scientific World Journal
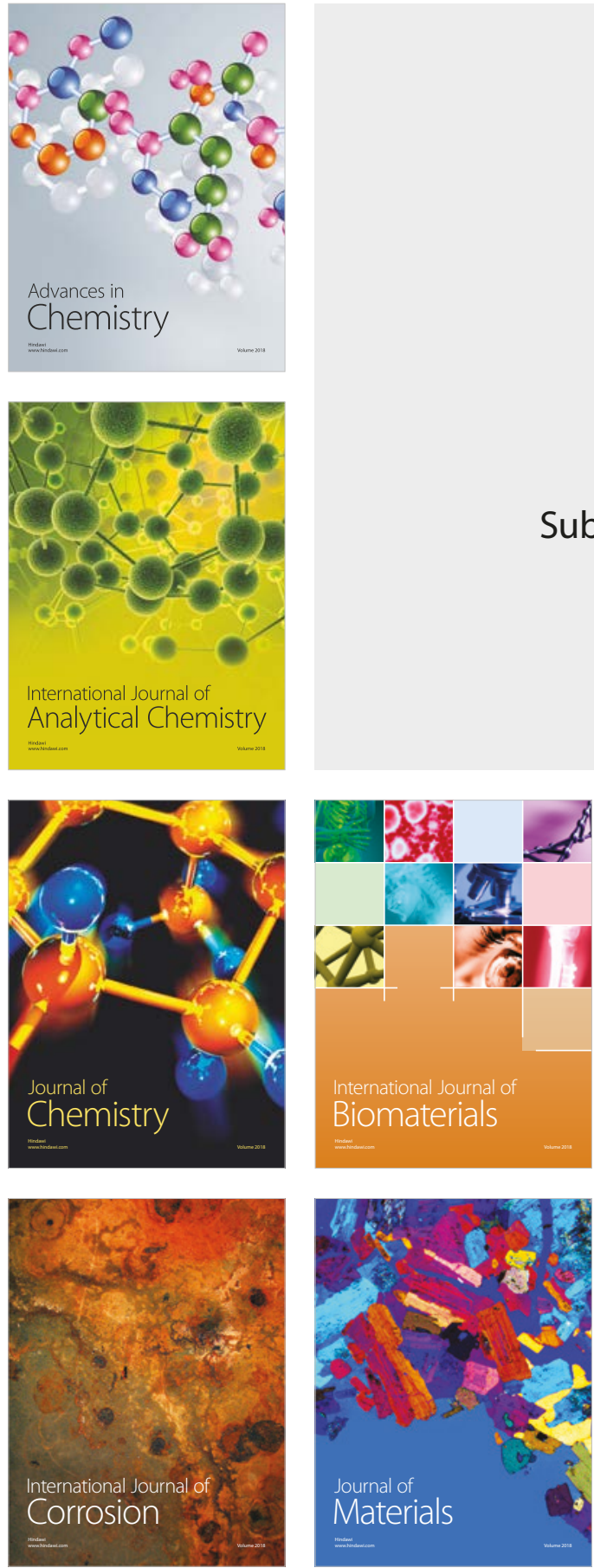

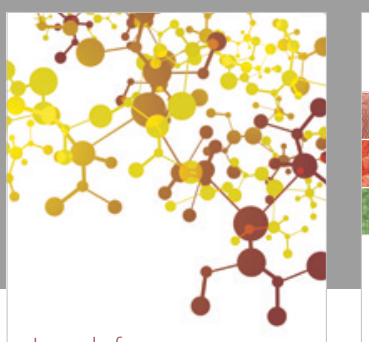

Journal of

Applied Chemistry
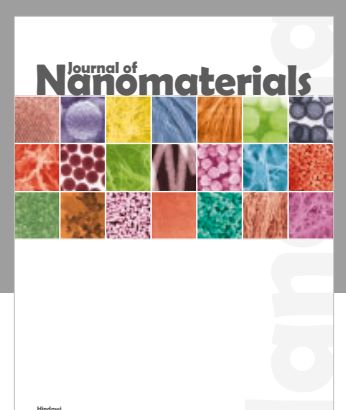

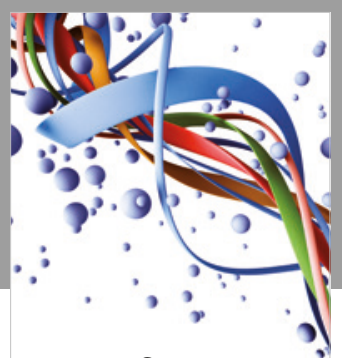

Scientifica

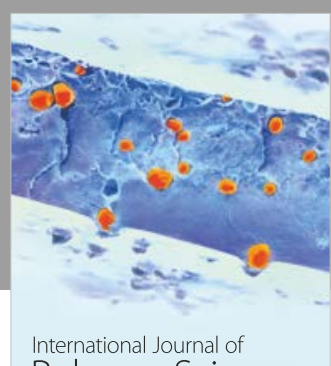

Polymer Science

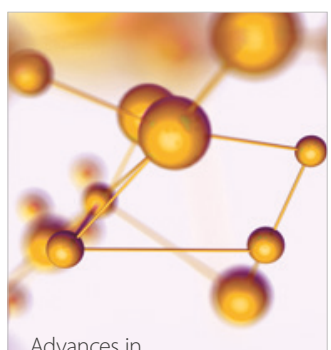

Physical Chemistry
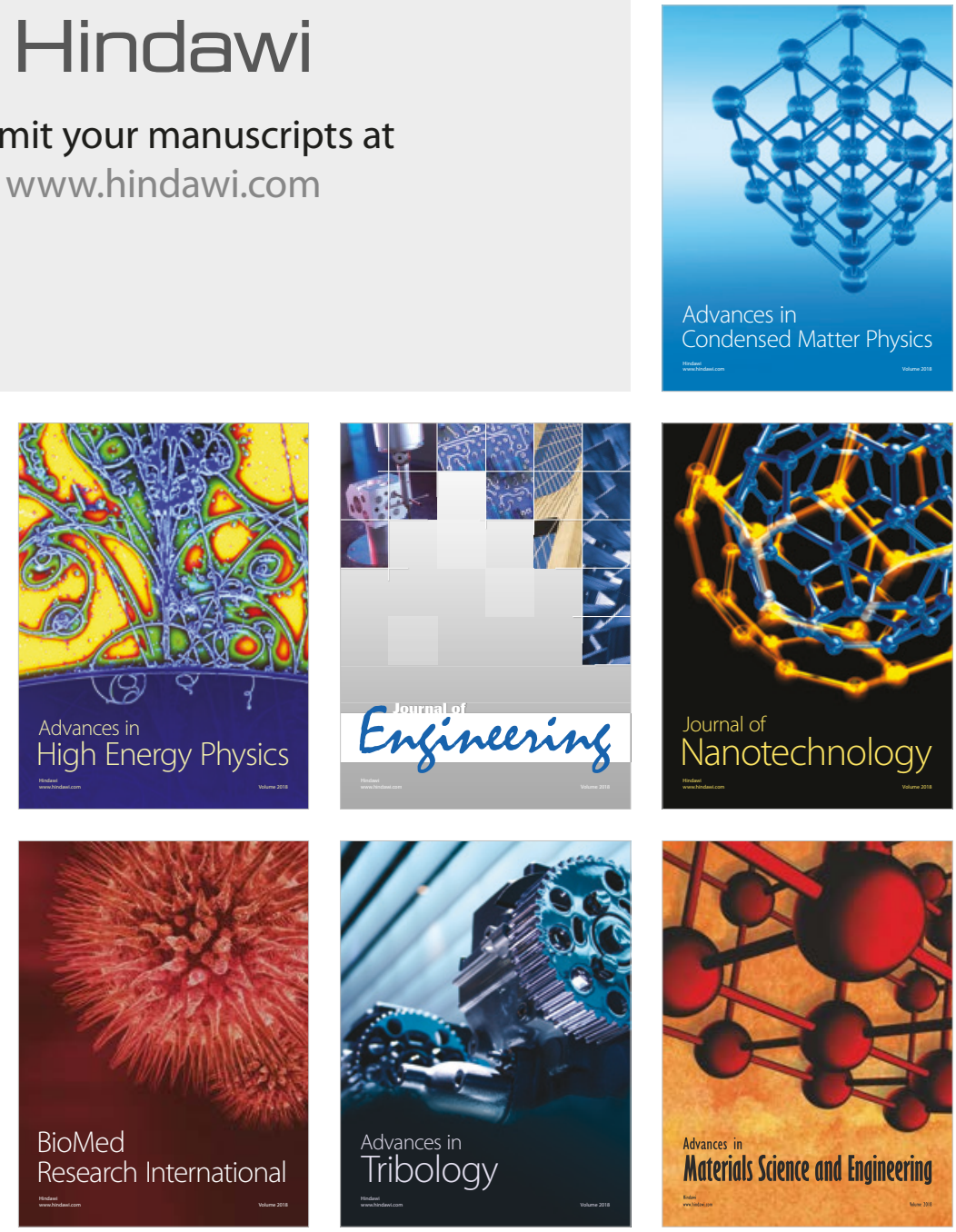